\title{
A Persian City During the Great War
}

\section{Hajji Baba}

To cite this article: Hajji Baba (1921) A Persian City During the Great War, Royal United Services Institution. Journal, 66:463, 463-468, DOI: 10.1080/03071842109434624

To link to this article: http://dx.doi.org/10.1080/03071842109434624

\section{曲 Published online: 12 Nov 2009.}

Submit your article to this journal $\pi$

山 Article views: 33

Q View related articles $₫$ 


\title{
A PERSIAN CITY DURING THE GREAT WAR.
}

\author{
By Hajji Baba. \\ "The dogs bark, but the caravan passes on." \\ -Old Proverb.
}

IN Western Persia in the Autumn of 1914 the most noticeable signs of the Grent VVar were the gradual rise in prices, the irregularity of the mails, and the exodus of Germans from Persia via Baghdad instead of the usual Caspian Sea route. Since the Kalhurs and Galkhanis were at that time exacting heavy blackmail from all caravans and travellers on the Kermanshah-Qasr-i-Shirin road, most of these Germans had an adventurous time. Two from Teheran were kept in chains for several days at Sar-i-Pul, severely beaten, and forced to pay eighty tomans.

The first German political agents to arrive in Kermanshah were Schunemann and his assistant, Paschan. They established themselves there early in 1915. The former came ostensibly as German Consul. He had been in Persia for years, at first in Azerbaijan with the Lepsius Mission, which conducted schools and orphanages for Syrians and Armenians. He was a carpenter by trade, but shrewd and well fitted for the difficult task assigned to him. At first the representatives of the allies, which included the British and Russian Consuls and a Russian captain in charge of several hundred P'ersian cossacks, did not regard the presence of Schunemann as a menace, but they soon became aware that these Germans were spending money lavishly and had gathered round them a formidable body of armed retainers. They maintained their own bodyguard, and paid large sums to influential men simply to remain neutral in case of trouble.

They also bought at high prices from the tribal chiefs guarantees to furnish certain numbers of men, both horse and foot, when called upon. These pioneers of German propaganda were quickly followed by others of the same mould, most of whom travelled with consular passports. They visited all the gendarme posts and got into close touch with the Swedish and Persian officers. Some pretended to be engaged in scientific pursuits and one, who afterwards became prominent in southern Persia, was making a collection of insects. An important iten on their programme was the circulation of cleverly prepared literature.

Early in the spring of 1915, Husain Raouf Bey, with a force of about two thousand, partly regulars belonging to the $37^{\text {th }}$ Division and the remainder Jof and other Kurdish tribesmen, crossed the Persian frontier and came up as far as Kerind. The people of the 
district protested against this advance and some of the chiefs, including Ali Akbar Khan of the Sinjabi tribe, telegraphed to Teheran for permission to drive the Turks out. The government, however, paid no attention, and so the allied representatives left Kermanshah about the middle of April and went to Hamadan, which gave Schunemann and his clique complete control of the district. The Turks had not been long in Kerind before the people of that neighbourhood, angered by wanton acts of violence on the part of the soldiers, attacked the camp. Ali Akbar Khan rode from Kermanshah to Kerind in one day to take part in the fight. Many 'Turks were killed, but Husain Raouf Bey with his guns drove off the attackers and looted the village. As this was not down on the programme at all, Schunemani went to Kerind and persuaded the Turks to go back to Mesopotamia. In spite of this episode the Germans pushed their preparations as rapidly as prudence would permit. They brought in quantities of arms and ammunition. Officers arrived and began to drill the native levies. The gendarme officers, both Swedish and Persian, openly affirmed their allegiance to Germany, and thousands of Kurds, Lurs, and Persians were soon in German employ and in process of being trained to fight Russia. It is curious to note that the hostility of the Swedish officers of the gendarmeric to the allies was not realized in India for some time.

In the summer of 1915 the British and Russian consuls attempted to return to Kermanshah. Accompanied by a few cossacks and their own personal Persian retainers; they got as far as Kangavar, but Schunemann arrived at Sahneh about the same time with a force of several hundred Lurs and refused to allow them to proceed. After a delay of more than a fortnight, and much fruitless negotiation for a suitable Persian escort, the consular party was attacked. The Persian guard holding the village did not show much fight, and Schunemann was soon master of the situation. The consuls returned to Hamadan and the Germans to Kermanshah. This little affair gave Schunemann great prestige and did more to link the people of the district with Germany than any vaunted victory on the western front could have done.

Matters came to a climax about the end of November. The gendarmes confiscated the British banks in Hamadan, Sultanabad, and elsewhere, and the allied representatives in those places had to flee. The Russians had troops in Kazvin which, together with other places in northern Persia, they had garrisoned before the war. They at once despatched a force to Hamadan and sent movable columns to Kum and Isfahan. The design at Kum was to capture the German propagandists flecing from 'Teheran, but the refugees were too quick for the Russians. The Isfahan column was intended to stop German intrigue in those parts, and apparently succeeded. The Germans, with their gendarmes and levies, met the Russians near Aveh and were severcly handled, whereupon they evacuated Hamadan; while the Russians crossed over the mountains to Asadabad.

In January, 1916, the Germans brought up about two thousand Turkish troops to the Bidsurkh Pass, some five miles east of Sahneh, 
with a view to checking the Russian advance. This time the Turks gave guarantees of good behaviour to the Kerind people, who in return gave them safe conduct. The tribes were now so entangled in the German net and so afraid of the Russian cossacks that they welcomed the assistance of the Turks in the inevitable struggle.

This force was what Von der Goltz Pasha had designated the "Baghdad Group" and was composed partly of the remnants of the $37^{\text {th }}$ Division and partly of irregulars.

In mid-January, I916, they attacked the Russian advance guard, which consisted of about 350 cossacks and infantry, and compelled them to evacuate Kangavar and retire to Asadabad. These were the first Turkish troops to encounter the Russians in Persia.

For the first six weeks of 1916 life in Kermanshah was full of excitement, and murders and highway robberies occurred constantly in open daylight. The province was controlled by Nizam-es-Sultaneh, a former governor of Luristan and now the principal tool of the Germans, - who sat at the head of a sort of mock parliament in the city. On the 22nd February, however, there was a rude awakening, for on the 2oth the Russian ist Caucasus Cavalry Division, supported by the greater part of two battalions of infantry, had advanced from Asadabad. On the 2ist they took the Bidsurkh Pass, and most of the Germans left Kermanshah the following day. The city was panicstricken. The Swedes and Germans had everywhere circulated tales of Russian cruelty and violence, and for two days the Baghdad road was black with people moving down towards Mesopotamia. The last of the Germans and Swedes arrived from the front on the afternoon of the 23rd. They had very little transport and were therefore obliged to leave behind most of the stores collected at Kermanshah during a whole year. They had quantities of rifles and ammunition in their headquarters, and one of their number was told off to stay behind and blow up everything. They were still struggling with their personal belongings, and trying to load them on the few animals at their disposal, when the sound of the Russian artillery was heard from Kara Su bridge. This was soon accompanied by rifle fire, and the Germans and Swedes mounted and rode off without waiting to destroy anything. $\Lambda$ s the sun was setting the remnant of Turks entered the town. They were only a few hundred strong, and were haggard, hungry, and dropping with fatigue. The Russians had been pounding them all the way from Sahneh. They went into the government house, planted a gun on the roof, and refused to go any further that night. The Russians spent the night on the banks of the Kara Su and sent in a message demanding that a deputation under a white flag should meet them early in the morning and surrender the city. There was much running to and fro, and the next morning while it was still dark, a humble procession marched out to the Kara Su, bowed to the ground before the Russian cossacks nodding haughtily on their horses, and surrendered the city; at ten o'clock on the 24th February, 1916, the Russians entered. Kermanshah remained in their hands for the next four months. This force, which numbered about $4, \infty 00$, consisted 
principally, of cavalry and included one or two crack regiments "resting" from other fronts.

The cossacks followed up the Turks and Germans as far as Kerind; but did not attempt for some time to advance any further. If they had continued their pursuit and had made a demonstration towards Baghdad it might have changed the whole situation at Kut, as the Turks would have been obliged to detach an appreciable force to prevent them from joining hands with the British. The reason for their delay at this critical period is difficult to understand, the more so because at that time the ration strength of the Russians in this theatre exceeded forty thousand. The Russian excuse for not advancing was the rainy weather and their lack of transport. In the meantime the Bagindad Group withdrew from Persia and rejoined the Sixth Army which was still investing Kut.

In May, when Kut had fallen and the weather was getting hot, the Russians advanced towards Khanakin. They were without helmets and many of them were still in winter clothing. The cossacks rode round Khanakin, cut the Turkish communications, captured a few convoys, sabred some Turks and had then photographed, but the attack on Khanakin itself was a failure. The Russian artillery was now inferior to that of the Turks, and the Russians had to retire. The Tusks, having taken Kut, were now able to detach a large force to operate against the Russians, and the XIIIth Army Corps, consisting of the 2nd, 6th, and a composite division, together with an independent cavalry brigade-all weak units-was sent into Persia to pursue them. This corps suffered considerable casualties on the way up to Kermanshah. The Russians made a good withdrawal and left practically nothing of value for their enemies. The Turks entered Kermanshah on the ist July. There was an engagement lasting several hours on the hills to the south east of the city. The Russians fell back stubbornly across the Kara Su, and the Turks in attempting to follow them up were repulsed. The Russians then established themselves about sixteen miles east of Kermanshah. The Turks entrenched opposite them and then rested during the fasting month of Ramazan.

At the beginning of August, when the Turks were preparing to advance, the ammunition dump at their headquarters in Kermanshah, took fire, and many camels, mules, and donkeys, and several persons, were blown to pieces. The sound of the bursting shells made the townsfolk think that the Russians were bombarding the town again, and the Germans, who had opened a bank and a supply depôt, turned over their money and were on the point of leaving when they found out what had happened. Driving the Russians before them, the Turks marched to Hamadan in six days, arriving there on the 11th August, 1916. As a result of this fighting about two hundred Turkish wounded were brought back to Kermanshah. The troops quartered in Hamadan consisted of the 2nd Division (Ist, 5th and 6th Regiments), the 6th Division (16th, 17th and 18th Regiments), and the 44th Regiment. The people of the city were pleased when they came in, but still more pleased when they went out. 
The Turks now had a great many sick. All sorts of diseases were rife among them, especially cholera, typhus, and malaria. They had eleven hospitals in Kermanshah, with an average of two thousand sick in them all the time. There were only five doctors to look after these hospitals, and there were practically no medicines. The equipment in the surgical hospital was marked "British Red Cross," and was captured in Kut. During the nine months of the Turkish occupation there was probably never a day without some deaths, and the mortality once rose to thirty a day. The Turkish commander, Ali Ihsan Bey, published an order threatening to hang all the doctors if the record did not improve. When the liurks left Kermanshah their cemetery contained at least 2,500 dead. In addition to the Anatolian Turks, who were of course the backbone of the Turkish force in Persia, there were Arabs, Jews, and a few Armenians. There were also about six hundred Algerian and Mloroccan Arabs captured from the French by the Germans at the beginning of the war. None of these nationalities succumbed to disease as did the Anatolian Turk.

The 'lurks had not been in Kermanshah long when the Germans again arrived on the scene. Nizam-es-Sultaneh and his cabinet also came back and re-established themselves there. The Germans tried to re-organize the gendarmerie and the battalions of levies, but the people were more wary. They were willing to take German money, but they flatly refused to fight. They were afraid of being drafted into the Turkish army, and since the action at Aveh they had a wholesome dread of Russian shrapnel and Russian cossacks.

It was remarkable how the Persian regiments would melt away when the Germans tried to put them into any position that seemed at all dangerous. The Germans became very disheartened and some of them did not hesitate to say that their mission was a failure. Early in 1917 , there were persistent rumours of an impending British advance in. Mesopotamia, but the first definite indication in Kermanshali of the march of events in that region was the hurried evacuation of the Turkish hospitals. It took a fortnight to get away the sick and to remove the grain and other essential supplies the Turks had collected in that city. They had practically no transport of their own, so they commandeered thousands of donkeys from the inhabitants. If a man were too ill to ride a donkey by himself he was held on by soldiers walking on each side of it. Men and animals died like flies all along the road.

On the morning of the gth March the sound of Russian guns was again heard on the Hamadan road, and by noon they were firing from the Kara Su bridge. That afternoon the Turkish main body withdrew into Kermanshah, having previously blown up one of the arches of the bridge, and the guns of their rear-guard shelled the Russians all that afternoon and throughout the next day. Late in the afternoon of the roth the Russians crossed the river by' a ford, but were thrown back. The Turkish army evacuated the city during the night, and on the morning of the $x$ th March their rear-guard, still shelling the Russians, was seen disappearing over the hills. 
Once more Kermanshah was under the Russians. They pursued the Turks as far as Pa-i-Tak, where Ali Ihsan Bey held them up for more than a week till his preparations for crossing the Sirivan river were complete. When the weather grew hot, the Russians evacuated Qasr-i-Shirin and the adjacent country, but they retained a garrison at Kerind through the summer until their animals had eaten or destroyed the harvest. The effect of the revolution was already very noticeable in the discipline of their troops. Officers were disobeyed and even threatened, and the men did as they pleased.

The Russians had a great deal of trouble with the Kurds. The tribes were at first willing to make friends, but the now undisciplined soldiers committed various acts of violence and roused the anger of the Kurds. The Galkhani tribe was especially active, and Russian convoys were attacked and camps raided constantly. The Russians in retaliation looted various villages along the road, Kerind itself suffering severely. In August a meeting was held with the tribal chiefs and a truce was arranged, but both parties were distrustful, and when the Russians went to Mesopotamia in the autumn to join the British they avoided the main road and marched by way of Gilan.

From time to time, all through the summer and autumn, parties of Russians left for home, but they were still in evidence in the beginning of 1918 when General Dunsterville's force began to arrive. They evacuated the city soon afterwards, and for the next three years Kermanshah enjoyed the blessings of British occupation. Fields were cultivated that had not been touched for years; travellers came and went without fear of molestation or blackmail; and once more the old road rang with the music of the caravans.

From this brief record of events it will be seen that within a space of three years the quaint old Persian city of Kermanshah was occupied twice by the Turks and Germans, twice by the Russians, and once by the British, which, considering that Persia was a neutral country, affords a striking indication of how widespread and continuous was the havoc wrought by the Great War.

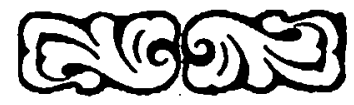

